
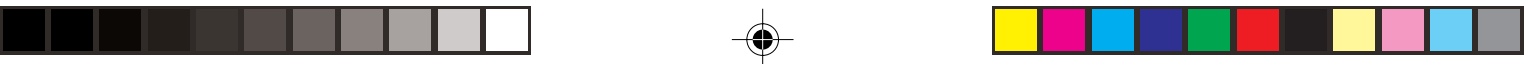

\title{
Enquête: Jeg har ingen illusioner...
}

Jeg har har ingen illusioner. Han var en mand uden illusioner. Jeg har tabt mine illusioner. Bristede illusioner.

Der er noget trist og bittert ved ordet illusion.

Jeg drømmer om... Den store drøm. Hun har mange drømme.

Drøm og illusion er aspekter af samme uvirkelige forestillinger på hver sin måde. Drømmen som indeholder håb, optimisme, forventning og illusionen som rummer det farlige, skæbnesvangere og skuffende. Et blændværk som er hult og uden sandhed. Noget som aldrig bliver virkeligt i modsætning til drømmen som dog har håbet. I ordet illusion ligger allerede begyndelsen til svigt. Hun norede store illusioner om ham. Underforstået, som viste sig at være usande.

Illusionen er forførelse. Det er noget nogen bevidst lokker med. Man lader sig blænde og begynder at drømme drømme som illusionen kun kan svigte.

Medmindre vi allerede på forhånd ved, at der er tale om en illusion og derfor ved, at det vi indlader os på er snyd. I så fald spiller vi med og lader os villigt forføre. Vi giver os hen og lader illusionen være en drøm, indtil vi forlader biografen. Forført af flade billeder på et stort lærred.

Illusionen er således kunstens vigtigste virkemiddel. I kunsten forlanger vi forførelse og skuffes hvis illusionen ikke er god nok til selvforglemmelse. Men når det sker og vi forføres, forvandles illusionen til rigtige drømme og derved fra noget negativt til noget godt og brugbart.

Ordet. Det talte ord er det stærkeste middel mennesker ejer i forholdet til hinanden. Ord er i deres udgangspunkt noget positivt. Vi tror på dem og opdager først senere løgnens muligheder. Men først tror barnet på alt hvad der siges. Vi kan slet ikke fungere som sociale væsner, hvis ikke vi tror på hinanden og har tillid til, at det vi hører er sandt. Vi vil høre sandheden, det vi tror er sandheden eller vælger at høre som om det var sandhed. Ordet kan i skreven form skabe eliter og magt, der kan undertrykke og manipulere, men det talte ord mellem mennesker er stærkere og skaber revolutionen, oprøret og krigen og atter freden. Jamen, han har ingen tøj på. Det sagte kan ikke være usagt og illusionen om at kejseren har tøj på er brudt og kan ikke repareres. Jeg elsker dig ikke mere gør på et øjeblik kærligheden til en illusion og alt er slut.

I den forstand kan mundtlig historiefortælling skabe den stærkeste kunstneriske illusion, fordi den til forveksling ligner virkeligheden. Den der har ordet kan skabe verden på ny. Ord skaber billeder. Billeder af noget bedre, mere grusomt og sjovere og fra den elskedes mund søger vi bekræftelsen på kærligheden. Den store taler river folket med sig og historiefor- 
tælleren kan, når han er god, gøre selv det mest usandsynlige troværdigt. Alene fordi det bliver sagt og fordi vi alle så gerne vil tro på det sagte. Ord skaber billeder. Billeder som er vore helt egne og som ligner vore drømme - de drømme der er pejlinger af os selv. Teater, film og alle andre kunstarter har ting og remedier hvormed illusioner understreges og støttes, men fortælleren er blot et mennesker der taler. Som kun siger ord til andre.

Hans Laurens

Fortaller 